\title{
Photoelectrosplitting Water Mechanism at Carbon Electrode Surface using Indoor lights
}

\author{
Rahadian Zainul $^{1 *}$, Admin Alif ${ }^{2}$, Hermansyah Aziz $^{3}$, Syukri Arief $^{4}$, Syukri $^{5}$ \\ ${ }^{1}$ Laboratory of Computational and Electrophotochemical Chemistry, Padang State \\ University, Air Tawar, Padang \\ ${ }^{2-5}$ Laboratory of Electrophotochemical dan Nanomaterial Chemistry, Andalas University, \\ Limau Manis, Padang \\ *Corresponding Author
}

This research aims to investigate process and mechanism of splitting water by illumination copper oxide using indoor lights. We report here an innovative approach, in which the lights are used from low energy and rarely never using in general photovoltaic system. The illumination is monitoring with high resolution CMOS Camera, 13 MPixel of OPPO X9006, to capture image of spliiting water. Splitting of water to produce hydrogen due on the Carbon (Graphite) electrode surface with electricity current from $\mathrm{Cu}_{2} \mathrm{O} / \mathrm{Al} \mathrm{PV}$ Cell and $\mathrm{Na}_{2} \mathrm{SO}_{4}$ electrolyte. Tandem of PV cell and Electrolysis Cell (PVEC) produce Hydrogen gas, in which electric current is 4.27 Voltage and $0.920 \mathrm{~mA}$ in $\mathrm{Na}_{2} \mathrm{SO}_{4} 0.5 \mathrm{~N}$ optimal condition. PV Cell use $\mathrm{Cu}_{2} \mathrm{O} / \mathrm{Al}$ as electrode with surface area $0.003711 \mathrm{~m}^{2}$. With eleven PV cell series arrangement (surface area $=0.018555 \mathrm{~m}^{2}$ ), produce voltage 4,27V (this voltage was exceed minimum voltage for water splitting with voltage $4,27 \mathrm{~V}$ ) and current $0.910 \mathrm{~mA}$. The process of water splitting observed at initiation of formation $\mathrm{H}_{2}$ gas and $\mathrm{H}_{2}$ release at carbon surface. After 1 hour and 50 minutes, $\mathrm{H}_{2}$ gas volume produced reach $0.00281 \mathrm{~mL}$.

\section{Keywords : Mechanism, Photoelectrosplitting, Indoor Lights, Hydrogen}

\section{Introduction}

Technology of Photovoltaic has growing rapidly, such as organic Cell, DSSC, and the polymer solar cell (1). Some effort has done to develop reactor, to design a reactor container, reflector for light collectors, absorbers reflection or anti reflector, and n-p junction connecting systems. The other modification, solar panels as a sandwich layer and electrodes used models. All these efforts are intended to improve the conversion of photovoltaic cells $(1 ; 2)$.

Sunlight energy does not have negative impacts like fossil fuel. Its converting sun's energy was not have waste product so it is one of clean energy resource. Therefore, solar energy has great potential to become the future energy resource, with abundant stock and environmentally friendly(3). Its potential energy reaches $1000-1369 \mathrm{Watt} / \mathrm{m}^{2}$ or about $3.9 \times 10^{6} \mathrm{EJ}\left(1 \mathrm{EJ}=10^{18} \mathrm{~J}\right)$ from one year total energy $(4 ; 5)$ and only about 5-12 $\%(6)$. 
Research of photocell always emphasizes the utilization of direct sunlight that has a high intensity. The reactor was placed in an open space and designed to be able to interact with the maximum of Solar Cells reactor. Meanwhile, the reactor that can work in room light has not been widely studied. This is because room light has relatively low light energy and solar panels that can work effectively is still not developed. Another factor is the difficulty to directly transform the low-intensity light energy to commercial energy and direct storage such as batteries(7).

Development of photocells reactor that can use energy from room light with low intensity to another intermediate energy forms as a carrier, in the formation of hydrogen gas continuously, it becomes an attractive option. Room light was used is sunlight coming into the room and the irradiation from lamp, like a neon (8).

The conversion process can be done by making a tandem photovoltaic cells and electrolysis cells(PV-EC) to transform indoor light energy into electrical energy that adequate for the electrolysis of water $(1,47 \mathrm{~V})$ into hydrogen gases $(9 ; 10)$. In this study conducted a study on the mechanism of water splitting into hydrogen gas, by using videoimage capturing and modeled through calculation assumptions hydrogen gas bubbles on the Carbon Electrode surface.

\section{Experimental}

\section{Materials and tools}

The tools was used in this research are Oppo F7a X9009, multimeter (Heles), Lightmeter (integrated with android of OPPO), SEM-EDX (Hitachi S-3400N), XRD, neon Lamp (Philip 10 watt), paper, carbon paper, Furnace, analytical balance, and glass tools.

Materials was used in this research are glass (PT Asahimas), glass glue, $\mathrm{Cu}$ plate (PT Metalindo Sejahtera), Al Plate, Natrium sulfat $\left(\mathrm{Na}_{2} \mathrm{SO}_{4}\right)$ (Merck), gelatin, chloroform (Merck) and aquades.

\section{Method}

\section{Copper Oxide electrode preparation}

Copper Oxide electrode was prepared by calcinating $\mathrm{Cu}$ plate on various temperature $300,350,400,450$ and $500^{\circ} \mathrm{C}$, for 1 hour. The resulting Copper Oxide plate was caracterized with SEM EDX and XRD. 


\section{Photovoltaic cell preparation}

Design of Photocell has developed by Rahadian et al (2015) and preparing by designing like figure 1.

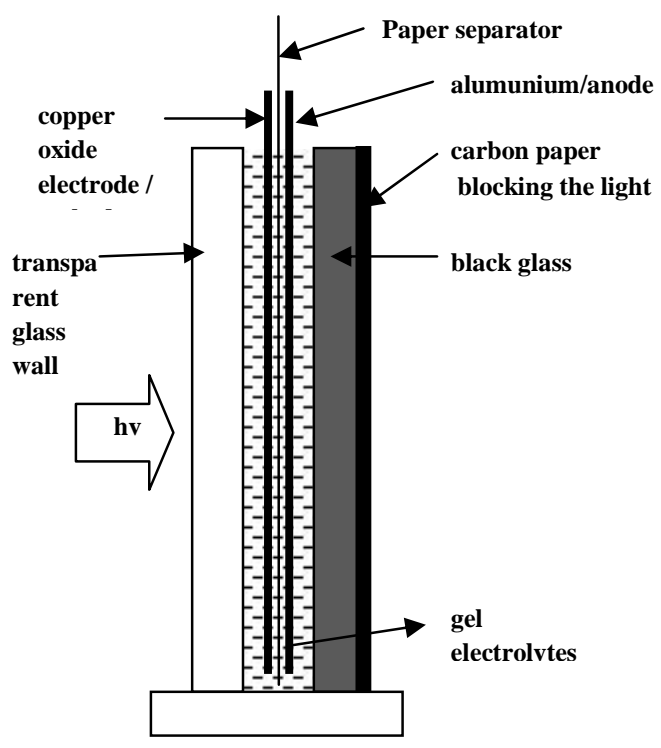

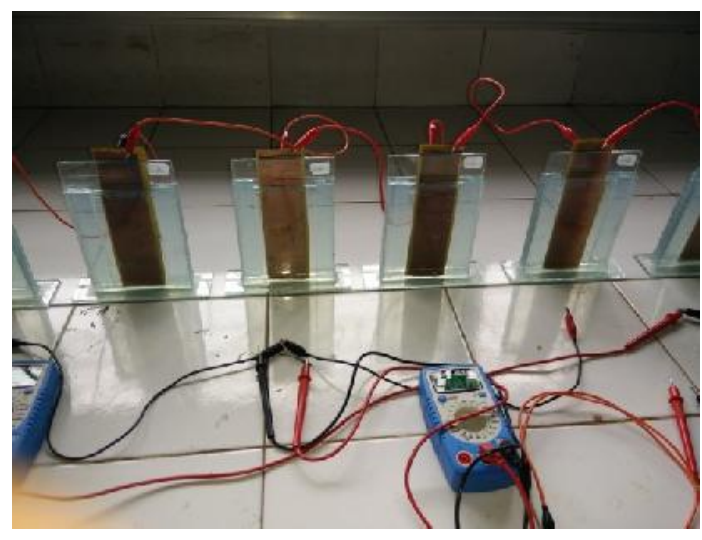

(b)

(a)

Figure 1. Design of Photocell (a) (7) and Pv building block cell (b)

\section{Natrium Sulphate $\left(\mathrm{Na}_{2} \mathrm{SO}_{4}\right)$ gelatin electrolyte preparation}

3,6 gram $\mathrm{Na}_{2} \mathrm{SO}_{4}$ was diluted with $100 \mathrm{~mL}$ water. Then, the solution was added 0,5 gram gelatin powder. The mixture was stirred and heated until boiling and become clean. After that was added some drops of chloroform and then solution was filled to cells directly.

\section{Current and voltage of $P V$ cells measurement}

Each PV cell was filled by natrium sulfate gelatin, then illumiation under room lights and neon lights. Current and voltage from cells was measured with multimeter. 


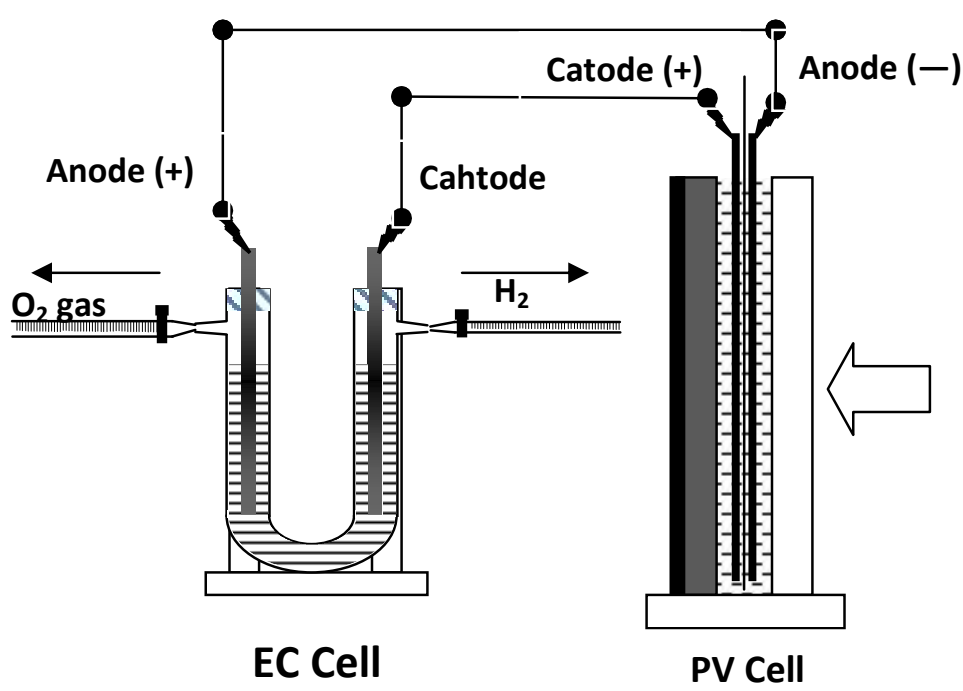

(a)

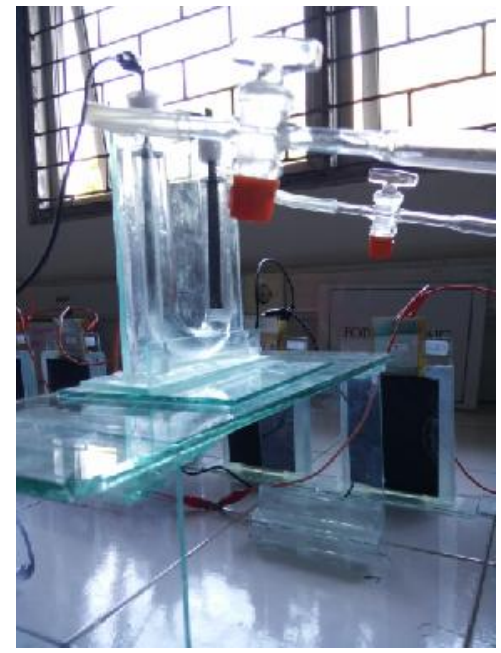

(b)

Figure 2. Scheme of design tandem reactor of Photo-Electro-cell (a) dan Photo-electrocell arrays (b)

\section{Measurement of Video-Image Capturing and Calculation Model of $\mathrm{H}_{2}$ Gas Bubble}

The formation of Hydrogen gas bubble at cathode in electrolysis cell was captured using Oppo X9006 (high resolution camera CMOS 13 megapixel). Measurement and calculation was done by using 50 time zooming for initial capture and record the mobility of bubble was observed with video capturing at surface of carbon electrode during splitting water into hydrogen takes place. This process was conduct for studying the mechanism of photoelectrospliting water into Hydrogen gas.

\section{Result and Discussion}

\section{PV Cell Arrays}

The Making of Electrode at PV Cell and Characterization by SEM-EDX-XRD

Plate of Copper with specification (thickness $0,27 \mathrm{~mm}$, and size $36,5 \mathrm{~cm} \times 120 \mathrm{~cm}$, and weight $1,2 \mathrm{~kg}$ ) was cut with size $4 \mathrm{~cm} \times 12 \mathrm{~cm}$. Plate was calcinated at 400 and $500^{\circ} \mathrm{C}$. The best performance was obtained with plate after calcinate at $400^{\circ} \mathrm{C}$. Copper oxide plate was used as cathode in PV cell. Meanwhile, for anode was used allumunium plate. 


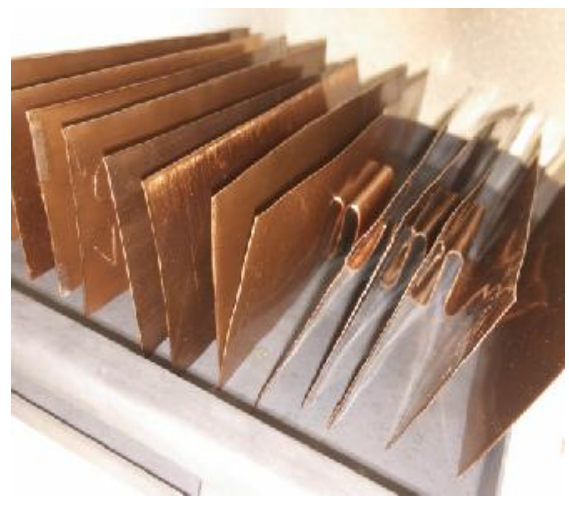

(a)

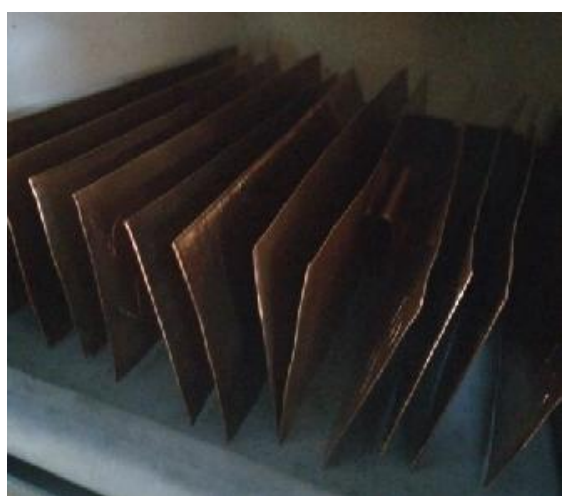

(b)

Figure 3. Photo of electrode plate (a) Copper before calcinations (b) Copper after calcination

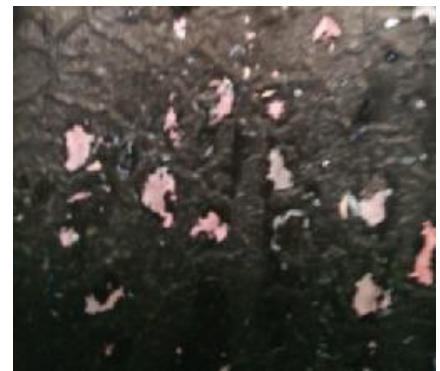

(a)

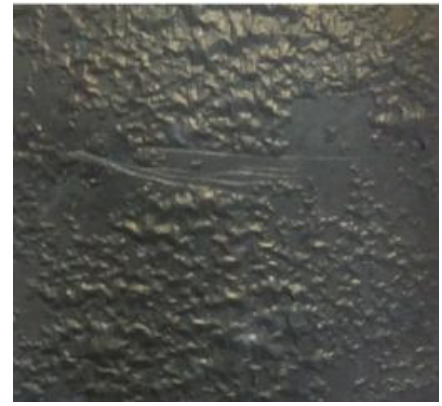

(b)

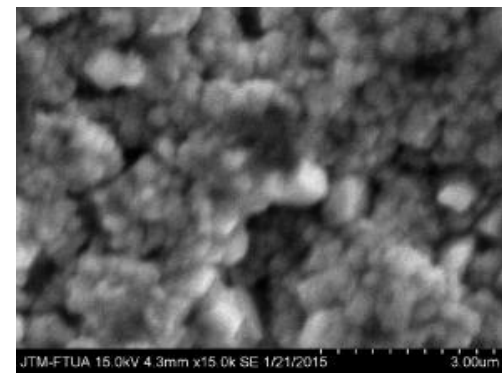

(c)

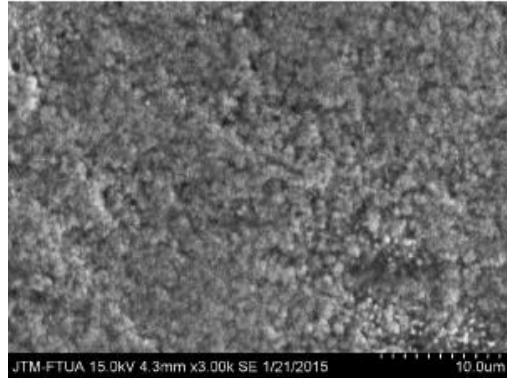

(d)

Figure 4. Image of oxide copper plate surface at $500^{\circ} \mathrm{C}$ calcinations (a) CMOS Camera (b) SEM with 15.000 times enlargement (c) image of plate at $400^{\circ} \mathrm{C}$ calcinations temperature and (d) SEM with 3.000 times enlargement

The formation of oxides on the surface by calcinating Copper plate has shown in Figure 4. The higher of calcination temperature, the oxide layer is formed more and more. This is due to the increasing number of reaction between oxygen atoms at the surface of the copper plate. From the camera catches Oppo X9009, visible changes on the surface of the copper plate before and after calcination. 
The EDX analysis show the amount of oxygen on the surface of the $\mathrm{Cu}$ plate which originally $1.22 \%$. After calcination at $400^{\circ} \mathrm{C}$ was obtained percent oxygen is $16.5 \%$. and $500^{\circ} \mathrm{C}$ percent oxygen on the surface of the $\mathrm{Cu}$ plate is $15.27 \%$ (7). Increasing of oxygen on the surface of the plate, will lead to an increase in the photocatalytic ability of the semiconductor material, since the formation of the conduction band(11).

Analysis of XRD for copper oxide plate after calcination at $400^{\circ} \mathrm{C}$, there two kind of oxides have formed, copper (I) oxide and copper (II) oxide with percentage $26.7 \%$ of copper (II) oxide $(\mathrm{CuO})$ and $73.3 \%$ of copper (I) oxide $\left(\mathrm{Cu}_{2} \mathrm{O}\right)(7)$. Formation of copper oxide under $1000^{\circ} \mathrm{C}$, that is mixture of $\mathrm{Cu}_{2} \mathrm{O}$ (firstly) and $\mathrm{CuO}$ (secondly) compound(12).

\section{The Result of PV Cell Power Measurement}

PV Cells has made the anode with plate Al, and Copper oxide as a cathode. The power PV cells was measured using multi tester and the result as shown in Table 1. Increasing the ability of PV cells is because the nature of aluminum plates such as n-type junction that provides electron more than plates $\mathrm{Cu}$ that are p-type junction(13). Therefore, plate $\mathrm{Al}$ causes a potential difference greater $\mathrm{PV}$ cell so as to produce greater power (7).

Table 1. Power of $\mathrm{Cu}_{2} \mathrm{O} / \mathrm{Al}$ photocell (7).

\begin{tabular}{|c|c|c|c|c|c|c|}
\hline \multirow{2}{*}{$\begin{array}{c}\text { Photocell } \\
\left(\mathrm{CuO} . \mathrm{Cu}_{2} \mathrm{O} / \mathrm{Al}\right)\end{array}$} & \multicolumn{3}{|c|}{ Room lights } & \multicolumn{3}{c|}{ Neon Lights } \\
\cline { 2 - 7 } & $\begin{array}{c}\text { Current } \\
(\mathrm{A})\end{array}$ & $\begin{array}{c}\text { Volt } \\
(\mathrm{mV})\end{array}$ & $\begin{array}{c}\text { Power } \\
\left(\mathrm{Watt}_{\mathrm{m}} \mathrm{m}^{2}\right)\end{array}$ & $\begin{array}{c}\text { Current } \\
(\mathrm{A})\end{array}$ & $\begin{array}{c}\text { Volt } \\
(\mathrm{mV})\end{array}$ & $\begin{array}{c}\text { Power } \\
\left(\mathrm{Wat} / \mathrm{m}^{2}\right)\end{array}$ \\
\hline $\begin{array}{c}\text { average 10 PV } \\
\text { Cell }\end{array}$ & 337.2 & 509.8 & 46322.97 & 318.3 & 438.7 & 37628.19 \\
\hline Seri 11 PV Cell & 497 & 3010 & 40311.78 & 517 & 3430 & 47785.23 \\
\hline
\end{tabular}

\section{I-V Characteristic Measurement}

$\mathrm{I}-\mathrm{V}$ characteristic measurement on photocell $\mathrm{Cu}_{2} \mathrm{O} / \mathrm{Al}$ shown in figure 5. The Photocell produce maximum power about $1.7331 \mathrm{mWatt}$, with 3.43 Volt and $0.513 \mathrm{~mA}$. Measurement was occurred at 590 flux and $54.81 \mathrm{ft}$ candle of neon lights. 


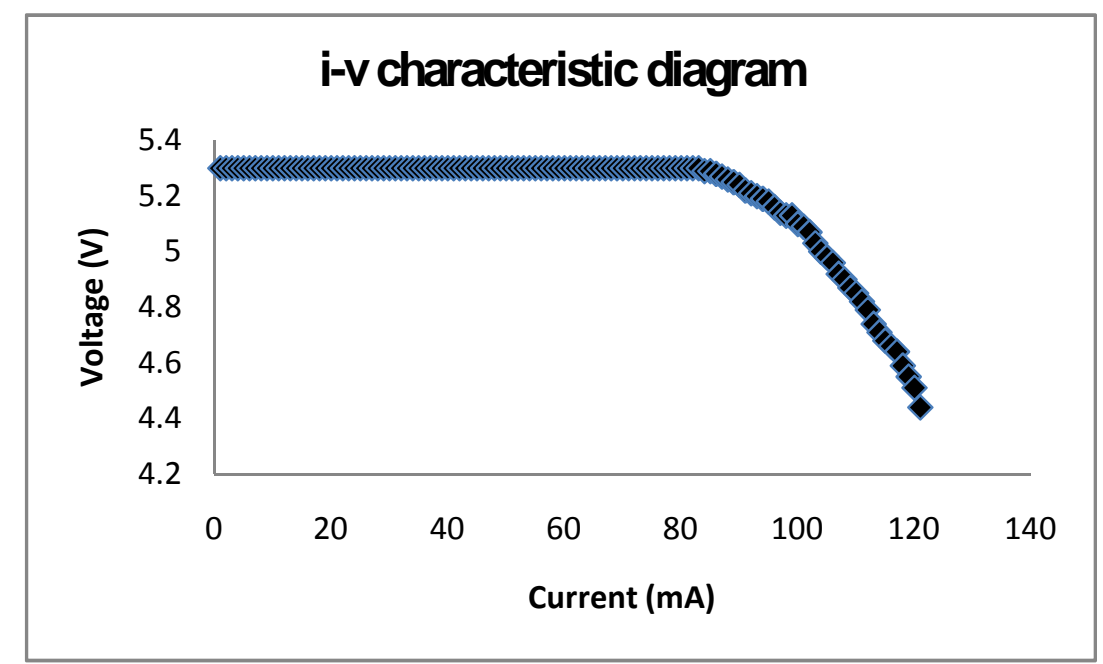

Figure 5. I-V characteristic diagram of photocell by illuminating neon lights

\section{Analysis of Capturing Image Scale Measurement}

Images of Carbon electrodes was taken with 13 Mpixel CMOS Oppo F7a X9009 done capturing image magnification and printed with HP Laser Jet printer. Size magnification to capture images was measured by comparing the scale of the actual size of the carbon electrode as a benchmark to get the actual size of the gas bubbles.

Results of measurement of the cross section of carbon electrode obtained the following results. Height/thickness of the carbon electrode (graphite) is $2 \mathrm{~mm}$, a width of $5 \mathrm{~mm}$ and height of $140 \mathrm{~mm}$. Measurement scale hydrogen gas bubbles using a crosssectional measurements in the vertical position on the wide position electrode $\mathrm{C}$ is $5 \mathrm{~mm}$. Photos printed electrode interface and conducted comparative measurement scale with the size of the cross section of carbon electrodes.

Table 2. Measurement of bubbles scale for gas $\mathrm{H}_{2}$ gas $(\mathrm{Big}=\mathrm{x} \mathrm{B}$, Medium $=\mathrm{x} \mathrm{S}$, and Small $=\mathrm{x} \mathrm{K})(7)$.

\begin{tabular}{|c|c|c|c|c|c|}
\hline $\mathrm{H}_{2}$ gas & \multicolumn{2}{|c|}{ Image Capturing } & \multicolumn{2}{|c|}{ Real } & $\begin{array}{c}\mathrm{H}_{2} \text { diameter } \\
\text { bubbles }(\mathrm{mm})\end{array}$ \\
\hline Sizes & $\mathrm{x}(\mathrm{mm})$ & $\mathrm{y}(\mathrm{mm})$ & $\mathrm{x}(\mathrm{mm})$ & $\mathrm{y}(\mathrm{mm})$ & 0.68182 \\
\hline Big & 3 & 22 & $\mathrm{x} \mathrm{B}$ & 5 & 0.45455 \\
\hline Medium & 2 & 22 & $\mathrm{x} \mathrm{S}$ & 5 & 0.22727 \\
\hline Small & 1 & 22 & $\mathrm{x} \mathrm{K}$ & 5 & \\
\hline
\end{tabular}

Based on the measurement scale camera capturing, hydrogen gasbubbleshave formed classified into three groups, i.e, large bubble (x B), medium bubble (x S) and small bubble (x K), with the size of each bubble are $0.68182 \mathrm{~mm}, 0.45455 \mathrm{~mm}$ and $0.22727 \mathrm{~mm}$. The formation of gas bubbles are monitored by camera catches, and shift of bubble in buret scale. However, the formation of $\mathrm{H}_{2}$ gas bubbles growth slightly, the 
method of measurement was done with a video recording on the surface of the carbon electrode for 5 hours and 45 minutes. Results recorded video capture on the surface of the carbon electrode was analyzed to get accurate results about the mechanism of formation of $\mathrm{H}_{2}$ gas bubbles (7).

\section{Analysis of Video Capturing at Carbon Electrode Surface}

We observe the capturing video for 5 hours 45 minutes, reported by calculating the scale on the image $13 \mathrm{MP}$ (Scheider certified professional camera)/50 Mega Pixel Photo Impresive Capturing from Oppo F7a X9006, when gas bubbles are formed and obtained by the real size scale comparators in image capturing. In this study actually gained diameter of each is $0.681818 \mathrm{~mm}$ for large size, $0.454545 \mathrm{~mm}$ for medium-size and $0.227273 \mathrm{~mm}$ for the small size.

The investigation of formation $\mathrm{H}_{2}$ gas bubble was reported Rahadian et al (2015). Bubble formation occurs at minute 10 , characterized by the formation of small bubbles (NBT) and the same time the formation of large bubbles (NBT). After 20 minutes, a bubble is formed again 1 large bubble (NBT) and 1 medium bubble (NST). Meanwhile, the release of gas bubbles occurred after 50 minutes of the release of 2 large bubbles (NBL). 8 minutes later, one huge bubble of $\mathrm{H}_{2}$ gas (NBL) was released from suface of elctrode. The counting process can be seen in Table 3 .

The process of the formation and transport of gas takes place at the time to 39:34 (39 minutes 34 seconds) is the No. 3 gas bubbles smaller gas bubbles move closer No. 4 larger. In the 45 th minute, $\mathrm{H}_{2}$ gas bubbles in point 4 was releasedform electrode surface. $\mathrm{H}_{2}$ gas bubble migration reaction was observed in the recording surface of the Oppo F7a. 26 seconds later, the initiation point reappear in the same location, namely point $4 . \mathrm{H}_{2}$ gas bubble nucleation No. 4 getting bigger and the same size as the gas bubbles No. 3 at minute 53. Both of these gas bubbles is approximately $5 \mathrm{~mm}$ and engaged with each other approaching at minute 53, second to 13 .

At the time of 01:10:57 (1 hour: 10 minutes: 57 seconds), both the bubble (No. 3 and 4) has migrated to the surface of the electrolyte from the electrode surface. 4 minutes later, point 3 and 4 re-emerged, and the process of formation of $\mathrm{H}_{2}$ gas re-occur. This process was observed for 5 hours 45 minutes of 0915 until 15:00 pm. The formation of gas bubbles as tabulated in Table 3. The term NBT, NST, HCV, respectively explain the large number of gas bubbles formed to size Large, medium and small. The term L, for the bubbles apart.

Table 3. The formation $\mathrm{H}_{2}$ gas bubbles at the cathode, $\mathrm{NBT}=$ number of large-size $\mathrm{H}_{2}$ bubbles formed, $\mathrm{NBL}=$ number of $\mathrm{H}_{2}$ large gas bubbles escaping from the cathode surface, $\mathrm{S}=$ medium, $\mathrm{K}=$ small, $\mathrm{t}=$ formed, $\mathrm{L}=$ apart $(7)$ 


\begin{tabular}{|c|c|c|c|c|c|c|c|c|c|}
\hline time & Minute & $\begin{array}{c}\mathbf{N} \\
\mathbf{B t}\end{array}$ & $\begin{array}{c}\mathbf{N} \\
\mathbf{B L}\end{array}$ & $\begin{array}{c}\mathbf{N} \\
\mathbf{S t}\end{array}$ & $\begin{array}{c}\mathbf{N} \\
\mathbf{S L}\end{array}$ & $\mathbf{N ~ K t}$ & $\begin{array}{c}\mathbf{N} \\
\mathbf{K L}\end{array}$ & $\begin{array}{c}\boldsymbol{\Sigma} \\
\text { bubbles }\end{array}$ & $\begin{array}{c}\text { Total } \mathbf{H}_{2} \\
\text { Volume }\end{array}$ \\
\hline $9: 15$ & $0: 00$ & 0 & 0 & 0 & 0 & 0 & 0 & 0 & 0 \\
\hline $9: 25$ & $0: 10$ & 1 & 0 & 0 & 0 & 1 & 0 & 2 & 0.000172 \\
\hline $9: 35$ & $0: 20$ & 2 & 0 & 1 & 0 & 1 & 0 & 4 & 0.000387 \\
\hline $9: 45$ & $0: 30$ & 4 & 0 & 1 & 0 & 1 & 0 & 6 & 0.000719 \\
\hline $9: 55$ & $0: 40$ & 4 & 0 & 2 & 0 & 2 & 0 & 8 & 0.000775 \\
\hline $10: 00$ & $0: 45$ & 4 & 0 & 2 & 0 & 3 & 0 & 9 & 0.000781 \\
\hline $10: 05$ & $0: 50$ & 4 & 2 & 1 & 0 & 2 & 0 & 9 & 0.001058 \\
\hline $10: 13$ & $0: 58$ & 4 & 3 & 2 & 0 & 2 & 0 & 11 & 0.001273 \\
\hline $10: 25$ & $1: 10$ & 4 & 3 & 3 & 0 & 1 & 0 & 11 & 0.001316 \\
\hline $10: 31$ & $1: 16$ & 3 & 4 & 4 & 0 & 0 & 0 & 11 & 0.001359 \\
\hline $10: 36$ & $1: 21$ & 3 & 4 & 4 & 0 & 1 & 0 & 12 & 0.001365 \\
\hline $11: 00$ & $1: 45$ & 3 & 4 & 4 & 0 & 1 & 0 & 12 & 0.001365 \\
\hline $11: 15$ & $2: 00$ & 3 & 4 & 5 & 0 & 0 & 0 & 12 & 0.001408 \\
\hline $11: 30$ & $2: 15$ & 3 & 5 & 4 & 0 & 0 & 0 & 12 & 0.001525 \\
\hline $11: 40$ & $2: 25$ & 3 & 6 & 3 & 0 & 0 & 0 & 12 & 0.001642 \\
\hline $11: 50$ & $2: 35$ & 3 & 6 & 3 & 0 & 2 & 0 & 14 & 0.001654 \\
\hline $12: 00$ & $2: 45$ & 3 & 7 & 3 & 0 & 1 & 0 & 14 & 0.001814 \\
\hline $12: 25$ & $3: 10$ & 3 & 8 & 2 & 0 & 1 & 0 & 14 & 0.001931 \\
\hline $12: 45$ & $3: 30$ & 3 & 8 & 3 & 0 & 2 & 0 & 16 & 0.001986 \\
\hline $13: 00$ & $3: 45$ & 3 & 9 & 3 & 0 & 1 & 0 & 16 & 0.002146 \\
\hline $13: 25$ & $4: 10$ & 3 & 9 & 3 & 0 & 2 & 0 & 17 & 0.002152 \\
\hline $13: 30$ & $4: 15$ & 3 & 9 & 3 & 0 & 4 & 0 & 19 & 0.002164 \\
\hline $14: 00$ & $4: 45$ & 3 & 9 & 4 & 0 & 3 & 0 & 19 & 0.002207 \\
\hline $14: 20$ & $5: 05$ & 2 & 12 & 4 & 0 & 1 & 0 & 19 & 0.002527 \\
\hline $14: 35$ & $5: 20$ & 0 & 14 & 4 & 0 & 1 & 0 & 19 & 0.002527 \\
\hline $14: 45$ & $5: 30$ & 0 & 14 & 4 & 0 & 2 & 0 & 20 & 0.002533 \\
\hline $15: 00$ & $5: 45$ & 0 & 16 & 3 & 0 & 1 & 0 & 20 & 0.00281 \\
\hline & & & & & & & & \\
\hline
\end{tabular}

From Table 3 have seen that the formation of gas bubbles occur is continuous for 5 hours and 45 minutes. Hydrogen gas bubbles after the point is established, then the bubble is enlarged on the surface of the electrode (cathode) and finally detached from the cathode surface to the water surface.

Nucleation point $\mathrm{H}_{2}$ gas bubbles begin to form after the tandem PV-EC work for 10 minutes 5 seconds. Based on the observations, $\mathrm{H}_{2}$ growing gas bubbles with a diameter of $0.68 \mathrm{~mm}$ as shown in Figure 5. Determination of $\mathrm{H}_{2}$ gas volume is formed by the following formula (assuming a spherical bubble of $\mathrm{H}_{2}$ gas). The volume of gas bubbles $\mathrm{H}_{2}=\mathrm{V}=(4 / 3)^{3}$. Where $\mathrm{r}=$ radius of $\mathrm{H}_{2}$ gas bubbles $(\mathrm{r}=1 / 2$ diameter $)$. Hydrogen gas bubbles are large in diameter $0.681818 \mathrm{~mm}$, then his fingers can be calculated, ie $\mathrm{r}=1 / 2$ $\mathrm{mm} \times 0.681818=0.340909 \mathrm{~mm}$. Thus, the volume of $\mathrm{H}_{2}$ gas bubbles are generated is $0167 \mathrm{~mm}^{3}$.

Table 4. Sizes and bubbles model of $\mathrm{H}_{2}$ gas

\begin{tabular}{|c|c|c|c|c|}
\hline Bubbles & $\mathrm{d}(\mathrm{mm})$ & $\mathrm{r}(\mathrm{mm})$ & $\mathrm{V}\left(\mathrm{mm}^{3}\right)$ & $\mathrm{V}\left(\mathrm{cm}^{3}\right)$ \\
\hline Big & 0.681818 & 0.340909 & 0.166027 & 0.000166 \\
\hline Medium & 0.454545 & 0.227273 & 0.049193 & $4.92 \mathrm{E}-05$ \\
\hline Small & 0.227273 & 0.113637 & 0.006149 & $6.15 \mathrm{E}-06$ \\
\hline
\end{tabular}


On the Figure 6 have seen that $\mathrm{H}_{2}$ gas bubbles is formed with variation sizes. There is three variations sizes, that small, medium and big, depend on $\mathrm{H}_{2}$ gas bubbles diameter on sectional electrode surface.

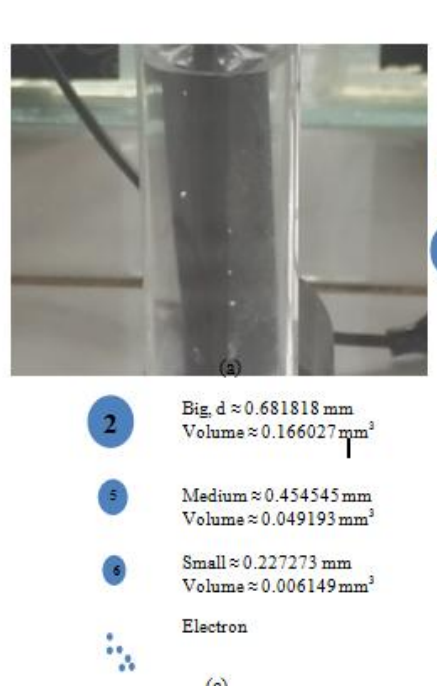

(c)

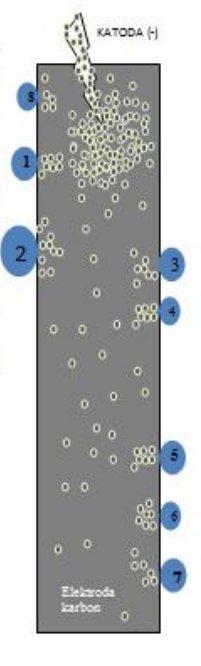

(b)

Figure 6. Gases bubbles image and models, (a) at carbon surface with 13 MPixel/50 time enlargement, (b) illustration of Hydrogen gas bubbles has formed in interface of Carbon electrode depend on electron distribution theory and (c) representation of $\mathrm{H}_{2}$ gas bubbles has formed.

\section{Theory of Hidrogen Gas Bubbles Formation}

Process of $\mathrm{H}_{2}$ bubbles formation on reaction taking place in water splitting at cathode surface.

$$
\begin{array}{ll}
\text { Cathode (-) } & : 2 \mathrm{H}^{+}+2 \mathrm{e} \rightarrow \mathrm{H}_{2} \\
\text { Anode }(+) & : 4 \mathrm{OH}^{-} \rightarrow \mathrm{O}_{2}+2 \mathrm{H}_{2} \mathrm{O}+4 \mathrm{e}
\end{array}
$$

Analysis of the formation of hydrogen gas on the surface of elektroda.Tahapannya is convection, migration and diffusion. The movement of electrons in the inner electrode is a process of convection currents generated from the electrolyte galvanic cell. In the electrolysis cell, the process of convection is the movement of electrons occurs towards the electrode surface. After the formation of hydrogen gas electrochemically, the movement of gases on the surface of the electrode is a migration process in translation. Gas will be shifted and eventually leave the surface of the electrode as the process of migrating from the liquid phase to the surface of the electrolyte solution. Finally, the movement of gas through the electrolyte to diffuse from the surface of the output pipe, toward the end of the gas storage.

Various factors affect the electrochemical transport period is a surface electrode, electrolyte environmental conditions, in addition to the main factor is the current and potential. The type of electrolyte used very effectively influence the migration process. 
Migration in acidic, alkaline and salt will have differences. Because of differences in the atmosphere of the electrolyte, affecting the conductivity of the solution. On the electrode surface, convection process is highly dependent on the structure of the electrode surface, which raises the style of style to the style of convection and gas formation on the electrode surface. Surface electrodes that are not symmetrical cause polarization on the electrode surface, as illustrated in Figure 7 (7).

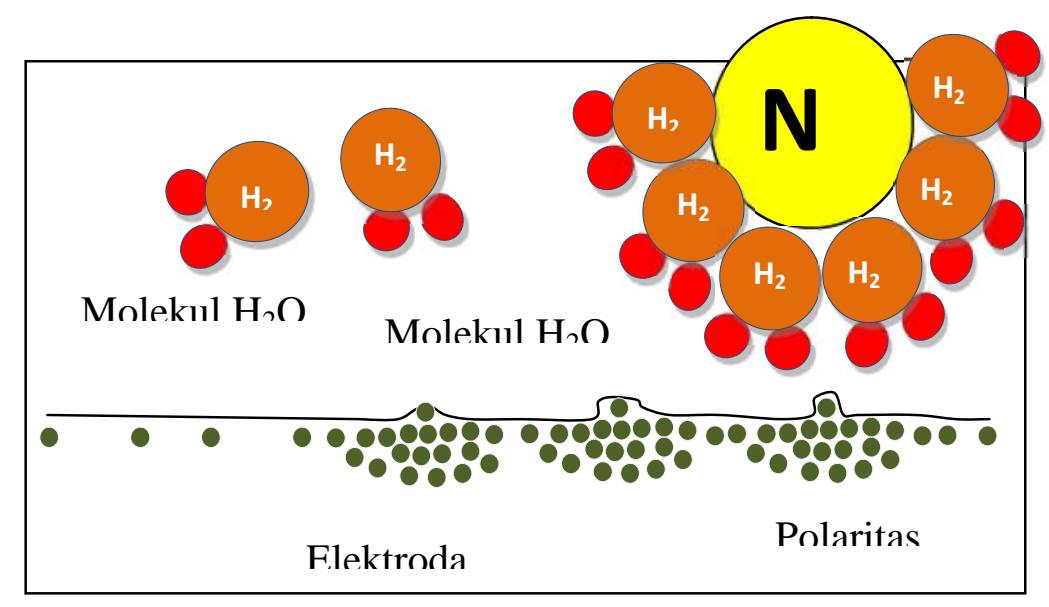

Figure 7. Schematic of electron polization on carbon electrode interface(7).

The phenomenon of the formation of hydrogen gas at the electrode surface was observed with the following stages. Initiation stage, which is the starting point of the formation of hydrogen gas. This point occurs on the surface of the effective where the convection of electrons on the surface of the electrode is more optimum and at this point there is also an effective collision of $\mathrm{H}_{2} \mathrm{O}$ with the active $\mathrm{C}$ interface electrode surface.

Reactions that occur at the initiation stage is the culmination point with the achievement of the activation energy so that the current that flowed on the surface of the carbon electrode (C), allows for the course of the electrochemical reaction of the hydrogen atoms that exist in $\mathrm{H}_{2} \mathrm{O}$ in the electrolyte solution. The electrochemical process, is a process of reduction at the cathode where the flow of electrons from the electrode surface to the hole point of the reactant species. At the same time, the oxidation reaction occurs at the anode where the reactant species that carry electrons give electrons to the hole area $(+)$ on the surface of the $\mathrm{C}$ electrode (anode).

Its reaction :

Cathode (-) $: 2 \mathrm{H}^{+}{ }_{(\mathrm{aq})}+2 \mathrm{e} \rightarrow 2 \mathrm{H}_{2} \rightarrow \mathrm{H}_{2(\mathrm{~g})}$

Anode (-) $: 4 \mathrm{OH}_{(\mathrm{aq})}^{-} \rightarrow \mathrm{O}_{2}+2 \mathrm{H}_{2} \mathrm{O}_{(\mathrm{l})}+4 \mathrm{e}$ 


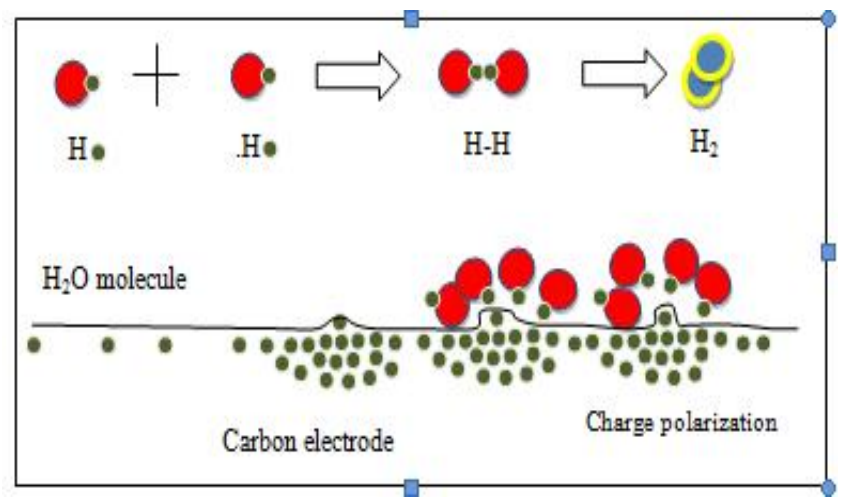

Figure 8. Scheme of $\mathrm{H}_{2}$ gas bubbles formation on $\mathrm{C}$ electrode surface (7).

The second stage is the formation of gas bubbles on the surface of the carbon electrode on the active side. This process was observed by the formation of small dots on the surface of the electrode that eventually become small bubble size diameter of $0.2 \mathrm{~mm}$ to $0.67 \mathrm{~mm}$. The starting point of the formation of gas bubbles called nucleation sites on the electrode surface. This gas bubble formation will inhibit the electrochemical processes at the electrode surface until $\mathrm{H}_{2}$ gas bubbles regardless of nucleation points (7). Phenomenon that occurs in the formation of $\mathrm{H}_{2}$ gas bubbles are:

1. The spontaneous formation of gas bubbles at nucleation sites. After the gas bubble diameter of $0.6 \mathrm{~mm}$, the bubbles is separated from the surface so that the electrochemical processes can walk back. During the nucleation process until the moment the release of $\mathrm{H}_{2}$ gas bubbles, the electrode surface has blocked for core nucleation reaction of $\mathrm{H}_{2}$ gas.

2. The movement of the electrode surface after nucleation of $\mathrm{H}_{2}$ gas formed at the adjacent position (about 1-3 mm) with some movement patterns. The movement of the point of $\mathrm{H}_{2}$ gas bubble size is very small tend to be attracted or moving closer to larger gas bubbles. The second movement of the other is moving closer to each other bubbles to form larger bubbles. The process of movement on the surface of the electrode runs translational and when the bubble is getting bigger, the next process is the process of release of $\mathrm{H}_{2}$ gas bubbles from the electrode surface.

On the electrode surface nucleation sites that are far away from each other, point 7 and 8 in the scheme of $\mathrm{H}_{2}$ gas bubble formation, the $\mathrm{H}_{2}$ gas discharge becomes difficult to occur. This can be overcome with the vibration of the electrode so as to increase the momentum of $\mathrm{H}_{2}$ gas bubbles and the gas transport leaving the electrode surface.

Rate of $\mathrm{H}_{2}$ gas production at cathode is $1.72 \times 10^{-5} \mathrm{ml} /$ minute in time range of first 10 minute, and its will increase in 1 hours after that, about $2.19 \times 10^{-5} \mathrm{~mL} /$ minute, thus finally decrease until $1.17 \times 10^{-5} \mathrm{~mL} /$ minute after 1 hours 50 minute. From table 3 , has been showed that after 6 hours, Hidrogen gas was achievely produced $0.00281 \mathrm{~mL}$.

\section{Conclusion}


Mechanism of $\mathrm{H}_{2}$ gas bubble formation occurs at the Carbon electrode surface with initiation process by nucleation point under indoor lights. We can make tandem photoelectro- cell has produced $3010 \mathrm{mV}$ voltage (room lights) and $3430 \mathrm{mV}$ voltage (neon light). Both of them can produce $\mathrm{H}_{2}$ gas bubbles with 2 step, which spontaneously bubble formation and nucleation-accumulation bubble formation. $\mathrm{H}_{2}$ production rate is $1.17 \times 10^{-}$ ${ }^{5} \mathrm{~mL} /$ minute.

\section{References}

1. Ur Rehman A, Lee SH. 2013. TheScientificWorldJournal 2013:470347

2. Wei D, Amaratunga G. 2007. Int. J. Electrochem. Sci. 2:897-912

3. Peter LM. 2011. Philosophical transactions. Series A, Mathematical, physical, and engineering sciences 369:1840-56

4. Parlevliet D, Moheimani NR. 2014. Aquatic biosystems 10:4

5. Zuttel A, Remhof A, Borgschulte A, Friedrichs O. 2010. Philosophical transactions. Series A, Mathematical, physical, and engineering sciences 368:3329-42

6. Hanmin Tian XY, Jiyuan Zhang, Wenfeng Duan, Fenglan Tian and Tao Yu. 2012. Int. J. Electrochem. Sci. 7:pg 4686-91

7. Zainul R, Alif A, Aziz H, Arief S, Syukri, Yasthopi A. 2015. Journal of Chemical and Pharmaceutical Research 7 (9s):246-56

8. Zainul R, Alif A, Aziz H, Arief S, Syukri, Munaf E. 2015. Research Journal of Pharmaceutical Biological Chemical Science 6.4. July-August:353-61

9. Kudo A. 2003. Catalysis Surveys from Asia Vol. 7, No. 1, April 2003

10. Sigfusson TI. 2007. Philosophical transactions. Series A, Mathematical, physical, and engineering sciences 365:1025-42

11. Sears WM, Fortin E. 1984. Solar Energy Materials 10 93-103

12. Musa. AO, Akomolafe T, Carter MJ. 1998. Solar Energy Materials and Solar Cells 51:305-16

13. Chien-Lin Kuo, Ruey-ChiWang, Jow-Lay Huang, Liu C-P, Chun-KaiWang, et al. 2009. Nanotechnology 20 (2009) 365603 (5pp):365603 (5pp) 